betydning, men man kan spørge, om Lunds bog ikke ville have vundet ved også at inddrage et mere teoretisk perspektiv på dømmekraften.

Lunds bog kan med fordel læses af folk, som vil have et indtryk af dømmekraftens konkrete og virkelighedsnære karakter og faktiske betydning i menneskets handlingsliv. Ønsker man en introduktion til dømmekraftsbegrebet, der går ud over dette konkrete og anvendelsesorienterede sigte, går man derimod forgæves. Manglende tekstreferencer og manglende anvendelse af og henvisninger til de faktisk foreliggende teorier om dømmekraftsbegrebet gør det vanskeligt at anvende bogen som andet end inspirerende lystlæsning - men dertil er den også velegnet.

Carsten Fogh Nielsen

\section{Diskursen om diskursen}

David Howarth: Diskurs - En introduktion. Hans Reitzels Forlag, 2005, 232 sider, kr. 248,-

Hans Reitzels Forlag satser for tiden på samfundsteoretisk litteratur og har i den forbindelse udgivet Stig W. Jørgensens oversættelse af Davis Howarths bog Discourse fra 2000. Howarth er lektor i politisk teori ved University of Essex i England. Begrebet 'diskurs' har i en årrække været et varmt emne inden for de samfundsfaglige og humanistiske videnskaber, så det må være både økonomisk fornuftigt for forlaget og givtigt for den interesserede akademiker med en grundig introduktion til dette tema.

På bagsiden af oversættelsen beskrives bogen som "en kort, men dækkende introduktion til de forskellige teoretiske positioner inden for feltet." Ved nærmere øjesyn bliver det klart, at den kun indfrier den første forventning: Bogen er kort, men er ikke dækkende, da den bevidst fokuserer på samfundsvidenskabernes brug af diskursbegrebet og koncentrerer sig om den franske tradition for (post)strukturalisme og (post)marxisme. Howarth indrømmer da også, at hans sympati ligger hos Laclau \& Mouffe, hvis diskursteori ihærdigt forsvares og forfægtes.

Indledningsvis opremser Howarth en genealogi over diskursbegrebets forandringer (her forstået som diskursanalyse). I den første fase var diskursanalyse forbundet med talehandlingsteori og fokuserede på regler for dagligsproget (Austin \& Searle, Garfinkel). I den anden fase i 1960'erne og 1970'erne blev begrebet udvidet til at inkludere sociale praksisser inspireret af strukturalisme, hermeneutik og marxisme. I denne periode var hovedpersonen naturligvis Foucault. Diskursanalysens anvendelsesmuligheder eskalerede yderligere $\mathrm{i}$ den tredje fase, hvor diskurs kom til at indbefatte hele systemer af sociale relationer. Denne tredje fase benævnes diskursteori og er identisk med Laclau $\&$ Mouffes position.

Resten af bogen er en kompetent 
gennemgang at de teoretiske positioner, der leder frem til Laclau \& Mouffes diskursteori. Vi bliver i kapitel 1 introduceret for Saussures og Lévi-Strauss' strukturalisme og i kapitel 2 følger Derridas poststrukturalisme. Kapitel 3 og 4 er viet til Foucault. Først gennemgås den yngre Foucaults arkæologiske metode og derefter den $x$ ldres genealogiske tilgang. Kapitel 5 omhandler postmarxismen i form af Gramsci, Althusser og Pêcheux, mens kapitel 6 gør rede for og forsvarer Laclau \& Mouffe. Bogen slutter af med et spændende kapitel om 'Diskursteori og praksis', der forsøger at vise, hvordan teorien kan benyttes som en metode $i$ forhold til konkret empirisk materiale. Metodologisk er det vigtigt for Howarth at distancere sig fra positivistiske og naturalistiske positioner inden for samfundsvidenskaberne. Diskursteori søger ikke kausale forklaringer og opstiller ikke almengyldige love. Som sådan er diskursteoretisk forskning konstruktivistisk og kontingent. Det betyder dog ikke, at man ender i forskningsmæssig anarkisme, når idéen om sandhed som en repræsentation af virkeligheden falder til jorden. Diskursteoretisk forskningskvalitet skal nemlig, som al anden forskning, vurderes i forhold til kollegerne, og ikke i forhold til virkeligheden: "Det forskersamfund, der består af de kritiske diskursanalytikere, og det, der består af samfundsforskere mere generelt, udgør det ultimative sandhedstribunal for samfundsvidenskabelig forskning." (s. 199) Hvordan kan man så bruge diskursteori i praksis ud fra dette konstruktivistiske udgangspunkt, der jo ingenlunde er forbeholdt diskursanalytikere? Howarth omtaler enkelte cases: apartheid-diskursen i Sydafrika og 'thatcherismen' i Storbritannien. Disse kan ses som 'afgørende case-studier', der kan inspirere til nye forskningsprojekter. I afvisningen af universelle regler og begreber i forskningsmetodikken er netop komparative studier, ifølge Howarth, en frugtbar vej at gå (s. 195). Diskursanalytikerens praksis minder om historikerens og antropologens: Det empiriske materiale kan således både være aviser, rapporter, personlige papirer, film, dokumentarudsendelser og deltagerobservation og kvalitative interviews. Spørgsmålet er så, om man er godt udrustet til at analysere sin empiri med Laclau \& Mouffes komplekse begrebsapparat i baghovedet. Det kan man, efter min mening, tvivle på og med fordel søge tilbage til Foucaults mere brugbare metodologi.

Konkluderende kan man sige, at Diskurs - En introduktion er værd at købe, hvis man vil stifte bekendtskab med den franske garde af strukturalister og diskursteoretikere. Mens den halter lidt som en generel introduktion til diskursbegrebet, er den et velartikuleret forsvar for moderne diskursteori.

Hans Henrik Hjermitslev 